desinteresse do exportador no cumprimento do contrato, em virtude da elevação do preço do produto que ele vai fornecer, já maior na praça; cobrança de sinistros, hipótese em que a insolvência se resolve no foro do domicílio do devedor, demandando a contratação de advogado local; e, finalmente, riscos quanto a defeitos de fabricação suscetíveis de cau- sar danos a terceiros (seguro de responsabilidade civil do produto, modalidade existente no Brasil mas quase não-utilizada pelo exportador), em que, na fase judicial, a ação não é movida diretamente contra o exportador, mas, sim contra o vendedor, pelo consumidor prejudicado, e pelo importador, por via regressiva, afinal, contra o exportador.

\title{
Garantias do crédito à exportação. Normas internacionais
}

George Rodrigues de Siqueira, assessor jurídico da Diretoria de Operações Cambiais do

Banco do Brasil S/A.

O comércio internacional não tem, por hipótese, fronteiras nem barreiras e está regulado por um conjunto de normas chamado a nova lex mercatória, que se apresenta sob quatro pilares fundamentais: os usos profissionais; os contratos tipo; as regulações ditadas pelo assento de cada profissão ou suas associações representativas; e a jurisprudência
George Rodrigues de Siqueira

arbitral. Mais recentemente surgiu um instrumento que procura estabelecer normas para as garantias internacionais. É a Publicação n. 325 da Câmara de Comércio Internacional, elaborada longamente por técnicos da Organização das Nações Unidas, que agiliza os negócios e os termos da garantia na área bancária.

\section{O risco de um Estado estrangeiro nas transações externas}

Eduardo Grebler, chefe da Assessoria Juridica da Construtora Mendes Júnior

A sistemática brasileira de crédito à exportação adota por princípio a linha de crédito ao vendedor - suply credits - , fazendo incidir sobre o exportador o risco da eventual inadimplência do importador estrangeiro.

A sistemática nada de grave apresenta intrinsecamente, exceto na hipótese das exportações de serviços, onde o exportador estrangeiro é na maioria ou totalidade das vezes um Estado ou pessoa ju-
Eduardo Grebler

rídica estatal. Nesses casos, quando há envolvimento de governo a governo, far-se-ia aconselhável a aplicação do sistema buys credit, não muito praticado entre nós.

A conseqüência principal desse estado de coisas é que o exportador brasileiro tem sido forçado a absorver o risco de um Estado estrangeiro, com acentuada desproporção de forças. 